\title{
An economic comparison of risk handling measures against Hylobius abietis and Heterobasidion annosum in the Landes de Gascogne Forest
}

\author{
Marielle Brunette ${ }^{1} \cdot$ Sylvain Caurla ${ }^{1}$
}

Received: 22 September 2015 / Accepted: 7 June 2016 / Published online: 27 June 2016

(C) INRA and Springer-Verlag France 2016

\begin{abstract}
- Key message Phytosanitary risks are an increasing threat for forest, particularly due to climate change. Risk handling measures are effective economic strategies to manage such risks, so that Economics may provide relevant methodology to address this new challenge.

- Context Hylobius abietis and Heterobasidion annosum are two phytosanitary risks generating increasing damage in the Landes de Gascogne Forest.

- Aims We provide an economic comparison of different existing risk handling measures against Hylobius abietis and Heterobasidion annosum.

- Methods We use the Land Expectation Value, i.e., Faustmann criteria, to compare the different scenarios.

- Results We find that for Hylobius abietis, chemical treatment and fallow seem to be economically preferable to the absence of risk handling measure. For Heterobasidion
\end{abstract}

Handling Editor: Marc Hanewinkel

Contribution of the co-authors The two co-authors supervised the internship of Alexandre Gourdy that provided the preliminary version of the article. The manuscript was written by the two coauthors. Marielle Brunette focused more on the section dedicated to Hylobius abietis while Sylvain Caurla provided the analysis for Heterobasidion annosum.

Marielle Brunette

Marielle.Brunette@nancy.inra.fr

Sylvain Caurla

Sylvain.Caurla@nancy.inra.fr

1 LEF, AgroParisTech, INRA, 54000 Nancy, France annosum, we show that local stump removal is always preferable to total stump removal and chemical treatment. Local stump removal should be preferred to fallow when contamination occurs during the second thinning. Finally, our results indicate that fallow is always preferable to chemical treatment.

- Conclusion Beyond the specificities of the case study, the paper proposes a methodology to analyze such a problematic.

Keywords Phytosanitary risks · Cause-oriented measures $\cdot$ Weevil $\cdot$ Fungus $\cdot$ Economics

\section{Introduction}

Climate change impacts forest health in both direct and indirect ways. On the one hand, temperature, solar radiation, rainfall, and atmospheric $\mathrm{CO}_{2}$ concentrations represent major direct drivers of forest productivity and forest dynamics (Scholes et al. 2014). On the other hand, climate change influences insect population dynamics and geographical shifts such as population release due to warmer winter temperatures (Bentz et al. 2010), as well as fungus development (Scholes et al. 2014), both of which increase the risks of invasion in forest ecosystems.

This relationship is already supported by recent observations in North America (Hogg et al. 2008; Michaelian et al. 2011) and Europe where an increasing incidence of disease has been observed in many forests (FAO 2008). Between 1994 and 2005, 57 \% of European forest damage was caused by biotic hazards, with $34 \%$ due to insects, $19 \%$ due to fungi, and $4 \%$ due to herbivorous mammals, whereas abiotic hazards were responsible for $22 \%$ of the damage and anthropogenic hazards for $21 \%$ (Jactel et al. 2012). In France, $14 \%$ of the trees are attacked each year by pests and 
$5 \%$ by fungi. They generate $81 \%$ of the overall observed damage in forests, of which $61 \%$ is caused by insects and $20 \%$ by fungi (Jactel et al. 2012). Such risks are likely to increase in the near future due to rising temperatures and an increased recurrence of major climatic events (Kovats et al. 2014). Moreover, it has been demonstrated that a rise in temperature leads to an increase of some biotic hazards (Rouault et al. 2006), whereas the increase in frequency and intensity of some natural hazards favors the development of phytosanitary problems (Desprez-Loustau et al. 2007; Berggren et al. 2009). In addition to these climate factors, human activities are also likely to increase species displacement rates by intentionally or unintentionally dispersing individuals or propagules. In particular, the increasing globalization of trade facilitates the import of exotic species, which may result in new biotic hazards (Roques et al. 2009; Desprez-Loustau et al. 2010).

Risk handling appears to be the most effective economic strategy to manage phytosanitary risks in the forest (Parker and Gilbert 2004; Jactel et al. 2009). In addition to conventional chemical treatments, other possibilities exist. They include the selection of tolerant or resistant families and clones in pure stands (Jactel et al. 2009), stump removal, and the preference for mixed-species forests as well as the use of a fallow period at the end of a forest rotation (Jactel and Brockerhoff 2007).

In the forest economics literature, risk handling measures are analyzed in many contexts and through various methodologies. For example, some authors proposed to analyze the mixed-stand as an efficient risk-reducing mechanism using portfolio theory (Knoke et al. 2008; Roessiger et al. 2011; Neuner et al. 2013). Other authors focus on the impact of risk handling measures against fire or storm on the optimal harvesting age in a Faustmann-type framework (Reed 1987; Thorsen and Helles 1998; Yoder 2004; Amacher et al. 2005). Another group of papers focuses on the effect of risk handling measures (species shift, reduction of rotation length, timing and intensity of thinning, planting density) on the forest land value in a Faustmann fixed-length rotation model (Goodnow et al. 2008; Brunette et al. 2014). Some surveys also deal with the handling of risk in a forestry context. In this vein, Hahn and Knoke (2010) linked risk handling strategies and precautionary principle, while Yousefpour et al. (2012) reviewed the decision-making approaches to handle uncertainty and risk in adaptive forest management under climate change.

However, to our knowledge, no paper addresses the risk handling measures of phytosanitary risks in forest through an economic approach. In this paper, our aim is to fill this gap by questioning the economic relevance of some existing risk handling measures against phytosanitary risks. For that purpose, we adopted a forest economics methodology based on the Land Expectation Value (LEV) calculation in order to compare existing strategies to face some phytosanitary problems. We applied our methodology to the Landes de Gascogne Forest both for geographical and economic reasons. The Landes de Gascogne Forest is located in southwestern France, near the Atlantic Ocean, where new pest invasion has become a major threat over the last decades. It is the largest cultivated and privately owned ( $92 \%)$ forest in Europe, primarily composed of maritime pine (Pinus pinaster), and covers two thirds of the Landes de Gascogne region. The forest plays a significant role in the economic development of the region through forestry and forest-based industries (Mora et al. 2014). However, the Landes de Gascogne Forest recently suffered from two major storms, Lothar in December 1999 and Klaus in January 2009, which weakened the biological equilibrium of the forest and its resilience capacity. Such extreme climatic events have facilitated phytosanitary risks. In addition, this forest is managed as a monoculture, a type of forest management resulting in a high sensitivity to phytosanitary problems (Jactel et al. 2008) since forest pathogens, insects, and fungi are often specific to a species and/or an age class. The two main phytosanitary risks that threaten the Landes de Gascogne Forest are a weevil (Hylobius abietis) and a fungus (Heterobasidion annosum). Hylobius abietis is the most common weevil in coniferous plantations during their early years (Canteloup and Castro 2012) while Heterobasidion annosum is a root fungus responsible for greater damage on the maritime pines of the Landes de Gascogne Forest (Piou and Jactel 2010). According to Woodward et al. (1998), it is considered to be the most economically important forest fungus in the Northern Hemisphere. In Europe alone, Heterobasidion annosum is responsible for the loss of $€ 800$ million annually ( $\$ 1$ billion US), and this fungus is also widespread in forests in the US. Assessments of economic losses due to Heterobasidion annosum are generally obtained by measuring the reduction in yield and value of timber. According to Gonthier et al. (2012), such estimates were performed in plantations of Sitka spruce (Picea sitchensis (Bong.) Carr.), Norway spruce, and Scots pine (Pinus sylvestris L.) but not on maritime pine. Both raise significant economic concerns in this region, and assessments of the economic costs and losses that they induce - along with the costs of the risk handling measures - are becoming a prerequisite to improve the decision-making process of private forest owners.

\section{Materials and method}

\subsection{Definitions}

According to Knight (1921), risk refers to a situation where the probability of the occurrence of a disaster is well-known, 
whereas uncertainty refers to a situation in which the probability of occurrence is not known. The probability of occurrence of some events may be difficult to estimate due to the lack or scarcity of past occurrences; in this case, only intervals of probabilities are available. In this paper, we refer to risk whenever the associated probability of occurrence of Hylobius abietis and Heterobasidion annosum is known, and we refer to uncertainty whenever the probability and/or the amount of the damage is not known.

In order to face risk, risk handling measures exist. They can be divided into cause-oriented or effect-oriented measures (Hanewinkel et al. 2010; Hanewinkel et al. 2011). Effect-oriented risk handling measures aim at reducing the amount of damage but do not reduce the probability of damage, while cause-oriented measures aim either at avoiding damage by abandoning risk-prone activities (risk avoidance) or at reducing the probability of damage by adopting preventive measures (risk prevention). In this paper, we focus on cause-oriented measures for two main reasons. First, a traditional effect-oriented measure is the transfer of risk to a third party through insurance contract, and such a contract is not available currently in France for phytosanitary risks in forest. Second, some measures allowing reducing the probability of occurrence of Hylobius abietis and Heterobasidion annosum and their associated damage exist. Indeed, for Hylobius abietis, we deal with two cause-oriented handling measures: a fallow that reduces the probability of risk occurrence (risk prevention) and a chemical treatment aiming at reducing the damage in case of risk occurrence (risk avoidance). For Heterobasidion annosum, we consider four cause-oriented handling measures characterized as risk prevention: chemical treatment, fallow, total and local stump removal.

Note that we focus on risk handling measures specific to the risks analyzed, Hylobius abietis and Heterobasidion annosum. In particular, the reduction of rotation length is not considered since it also prevents other natural events like storm and fire. The associated costs and benefits imputable to phytosanitary risks are therefore difficult to assess.

\subsection{Economic criteria}

It is assumed that the forest owner maximizes the forest's Land Expectation Value (LEV), i.e., Faustmann criteria (Faustmann 1849). For that purpose, we first calculate the Net Present Value (NPV) of costs and benefits for one rotation. The NPV is the present value of positive payments minus the present value of negative payments made at different points in time (Klemperer 1996):

$\mathrm{NPV}=\sum_{i=0}^{n} \frac{B_{i}-C_{i}}{(1+r)^{i}}$ where $B$ is the benefit, $C$ is the cost, $r$ is the discount rate, $i$ is the time period in years, and $n$ is the rotation length.

We then compute the LEV, defined as the sum of all NPVs:

$$
\begin{aligned}
\mathrm{LEV} & =\sum_{i=0}^{n} \frac{B_{i}-C_{i}}{(1+r)^{i}} \times \frac{(1+r)^{n}}{(1+r)^{n}-1} \\
& =\mathrm{NPV} \times \frac{(1+r)^{n}}{(1+r)^{n}-1}
\end{aligned}
$$

To compute the LEV, we assume that all rotations are identical, i.e., same time horizon, same sequence of events within each rotation, and same net revenue associated with each event within each rotation. In addition, we assume that the prices and the forest productivity are constant over time. Using the LEV makes it possible to compare silvicultural scenarios with different rotation lengths, as it will be the case, for example, when we will introduce the fallow as a potential risk handling measure.

\subsection{Case study}

The Forestry Company of the French Deposits and Consignments Fund (Societé Forestière de la Caisse des Dépôts et Consignations) defined a silvicultural standard for a monoculture of maritime pine in the Landes de Gascogne Forest. This standard includes both costs and benefits associated with this management practice, as indicated in Table 1 . We agreed on $3.5 \%$ interest rate.

This standard consists of a plantation of 1000 trees/ha, a clearing at year 2 of the plantation, two thinnings (year 12 and 22) and a final harvest at year 35 . We also consider management costs (machine maintenance, for example) for $€ 39 /$ ha/year, except for year 0 . Although these costs do not appear in Table 1, they are taken into consideration for the calculation of the NPV. For this standard, the density is equal to 500 trees/ha after the first thinning (year 12) and 321 trees/ha after the second thinning (year 22). In our

Table 1 Net benefits of a monoculture of maritime pine, the standard

\begin{tabular}{llll}
\hline Year & Operations & $\begin{array}{l}\text { Net benefit } \\
(€ / \text { ha })\end{array}$ & $\begin{array}{l}\text { Density } \\
(\text { trees/ha })\end{array}$ \\
\hline 0 & Plantation & -900 & 1000 \\
2 & Clearing & -70 & 1000 \\
12 & Thinning & 111 & 500 \\
22 & Thinning & 684 & 321 \\
35 & Harvest & 7228 & 0 \\
$\mathrm{NPV}_{\mathrm{S}}=816.86$ & & \\
\hline
\end{tabular}

The NPV is computed taking the additional management cost of $€ 39 /$ ha/year into account 
model, we assumed that the forest owner would want to keep these densities constant.

The NPV is equal to $€ 816.86 /$ ha $\left(N P V_{S}\right.$ in Table 1$)$, and the LEV is expressed as:

$\mathrm{LEV}_{S}=\mathrm{NPV}_{\mathrm{S}} \times \frac{(1+0.035)^{35}}{(1+0.035)^{35}-1}=€ 1166.91 / \mathrm{ha}$

In the rest of the paper, we first compare this LEV with those obtained when the risks are introduced, and we then compare the LEV with and without risk handling measures (either risk avoidance or risk prevention) when risks are considered. This helps us to determine the most economically relevant strategy. We separately analyze Hylobius abietis and Heterobasidion annosum.

\section{Results}

\subsection{Hylobius abietis}

Hylobius abietis is a little weevil that is spreading in France and causing major damage to young plantations. It develops under the bark of the host tree. A tree attacked by Hylobius abietis is necessarily lost. When plantation takes place the year after the final harvest, which is the common practice, the probability of invasion is certain, so we therefore assume a probability of invasion equal to 1 . The associated damage is uncertain, ranging between 50 and $80 \%$ for a stand with no risk handling measure. We consider that the damaged trees are not replaced. Therefore, the final stand will only be composed of non-damaged trees.

Two cause-oriented risk handling measures are available for Hylobius abietis. One possible risk prevention action consists in leaving the soil fallow for 2 years after the final harvest. In fact, when the site can be left unplanted for a sufficiently long period, the Hylobius abietis population and, therefore, the damage levels decline naturally. More precisely, the highest risk occurs over a period between 10 and
21 months after final harvest (Heritage and Moore 2000). After 2 years, however, the probability of attack on the stand is halved ( 0.5 compared to 1 without risk handling measure) and the mortality rate reduces to a level of $10 \%$ (compared to $50-80 \%$ without risk handling measure).

The second cause-oriented risk handling measure is a chemical treatment (risk avoidance). It consists in soaking the seedlings during the nursery stage in a solution containing cypermethrin (this strategy is referred to as FORESTER $®)$. An attack on a treated seedling leads to the death of the weevil, but the infested tree dies as well. This measure reduces the amount of the damage (25-30\% compared to the previous 50-80\% without risk handling measure) and has no impact on the probability of attack (which is still equal to 1 ).

\subsubsection{Without risk handling measure}

To deal with the uncertainty associated to the damage caused by Hylobius abietis, we assume three different values: 50,65 , and $80 \%$. We also assume that the damage occurs before the second operation on the stand, i.e., before year 2, as indicated in Table 2.

Table 2 reveals that between year 0 and year 2 , the higher the percentage of damage is, the higher the rate of mortality and the lower the tree density will be. For a mortality rate of $50 \%$ (resp. 65 and $80 \%$ ), the tree density decreases from 1000 to 500 (resp. 350 and 200). However, the objective of our forest owner is to conserve the density values of the standard, i.e., 500 trees/ha after the first thinning and 321 after the second one. This density is respected with a $50 \%$ tree mortality rate, partially respected with a $65 \%$ mortality rate (after the second thinning) and not respected at all with a $80 \%$ tree mortality rate.

Using Eq. 3, we then compute the LEV for each mortality rate, 50, 65, and $80 \%$, respectively: $\mathrm{LEV}_{H Y_{50}}=$ $€ 995.98 / \mathrm{ha}, \mathrm{LEV}_{H Y_{65}}=€ 72.77 / \mathrm{ha}, \mathrm{LEV}_{H Y_{80}}=€-$ 687.89/ha. As expected, the higher the potential damage is,

Table 2 Net benefits of a monoculture of maritime pine function of the damage due to Hylobius abietis and without risk handling measure

\begin{tabular}{|c|c|c|c|c|c|c|}
\hline \multirow[b]{2}{*}{ Year } & \multicolumn{2}{|c|}{ Damage of $50 \%$} & \multicolumn{2}{|c|}{ Damage of $65 \%$} & \multicolumn{2}{|c|}{ Damage of $80 \%$} \\
\hline & $\begin{array}{l}\text { Net benefit } \\
\text { (€/ha) }\end{array}$ & $\begin{array}{l}\text { Density } \\
\text { (trees/ha) }\end{array}$ & $\begin{array}{l}\text { Net benefit } \\
\text { (€/ha) }\end{array}$ & $\begin{array}{l}\text { Density } \\
\text { (trees/ha) }\end{array}$ & $\begin{array}{l}\text { Net benefit } \\
(€ / \text { ha) }\end{array}$ & $\begin{array}{l}\text { Density } \\
\text { (trees/ha) }\end{array}$ \\
\hline 0 & -900 & 1000 & -900 & 1000 & -900 & 1000 \\
\hline 2 & -70 & 500 & -70 & 350 & -70 & 200 \\
\hline 12 & -70 & 500 & -70 & 350 & -70 & 200 \\
\hline 22 & 684 & 321 & 52 & 321 & -70 & 200 \\
\hline \multirow[t]{2}{*}{35} & 7228 & 0 & 7228 & 0 & 4506 & 0 \\
\hline & \multicolumn{2}{|c|}{$\mathrm{NPV}_{H Y_{50}}=€ 697.21 / \mathrm{ha}$} & \multicolumn{2}{|c|}{$\mathrm{NPV}_{H Y_{65}}=€ 400.95 / \mathrm{ha}$} & \multicolumn{2}{|c|}{$\mathrm{NPV}_{H Y_{80}}=€-481.54 / \mathrm{ha}$} \\
\hline
\end{tabular}

The NPV is computed taking the additional management cost of $€ 39 / \mathrm{ha} /$ year into account 
the lower the LEV will be. However, it appears that the LEV does not decrease proportionally with the increase in the damage. As the damage increases from 50 to $65 \%$, the LEV decreases by approximately $42 \%$, whereas if damage increases from 65 to $80 \%$, the LEV decreases by approximately $220 \%$. Indeed, for damage between 50 and $65 \%$, the model assumes that the loss due to the weevil is compensated for by lower thinning intensities (years 12 and 22), without modifying the density after thinning operations. Since some of the thinned trees are damaged, their unit price is lower, which results in a decrease in the LEV. For damage between 65 and $80 \%$, the damage due to the weevil has a high direct effect on the density. Consequently, the number of trees standing just before final harvest is lower compared to the standard. The decrease in the LEVs results both from the reduction in density and from the decrease in unit prices due to damage to trees, explaining the higher reduction of the LEV compared to the two previous situations (damage of 50 and $65 \%$ ).

Moreover, the LEV for potential damage of $80 \%$ is negative, showing that keeping the trees standing is not an economically consistent option in this case. We compute here that the LEV is equal to zero for a percentage of loss of approximately $72 \%$.

\subsubsection{Chemical treatment: FORESTER®}

In this scenario, the seedlings are treated. The treatment costs $€ 0.03$ per seedling, which results in a total plantation cost of $€ 0.17$ (compared to $€ 0.14$ without risk handling measure). The treatment then costs $€ 30 / \mathrm{ha}$. Note that this treatment makes it possible to reduce the damage from 50 $80 \%$ to $25-30 \%$, as considered in the right hand side of Table 3.
Note that a reduction of the damage to $25 \%$ results in a density of 750 trees/ha at year 2, while a reduction to $30 \%$ corresponds to a density of 700 trees/ha at year 2 . The densities of the standard are respected after the first and the second thinnings, but since the pre-thinning density is lower, the net benefit at year 12 is lower compared to the standard ( $€ 20 /$ ha when the damage is $25 \%$ and $€ 2 /$ ha when it is $30 \%$, respectively, to be compared to the $€ 111 /$ ha of the standard).

Using Eq. 3, we compute the LEV of this scenario for the two percentages of loss, 25 and $30 \%$, respectively: $\mathrm{LEV}_{H Y_{C T 25}}=€ 1038.59 / \mathrm{ha}, \mathrm{LEV}_{H Y_{C T 30}}=€ 1021.49 / \mathrm{ha}$. The difference between the two LEVs is very small, approximately $1 \%$, whereas the damage increases by $5 \%$.

\subsubsection{Fallow strategy}

We assume that a 2-year fallow period occurs just before the beginning of the rotation to maximize the impact of fallow on the discounted final benefit. With this fallow, the site will be unplanted for a sufficiently long period to allow the Hylobius abietis population and hence damage levels to decline naturally (Heritage and Moore 2000). Consequently, the rotation goes from year 2 to 37 (compared to year 0 to 35 in the standard). The fallow period makes it possible to decrease the probability of attack from 1 to 0.5 . Moreover, the mortality rate decreases from $50-80 \%$ to $10 \%$. If the weevil attacks in the fallow scenario, the damage is equivalent to $10 \%$ (resulting in a density of 900 trees/ha at year 4). If the weevil does not attack, all operations are simply postponed by 2 years compared to the standard. The left hand side of Table 3 presents these two cases.

Using Eq. 3, we compute the LEV with fallow, both in the case of an attack (damage of $10 \%$ ) and in the case

Table 3 Net benefits of a monoculture of maritime pine function of the damage due to Hylobius abietis under a 2-year fallow period and chemical treatment

\begin{tabular}{|c|c|c|c|c|c|c|c|c|c|}
\hline \multirow[b]{3}{*}{ Year } & \multicolumn{4}{|c|}{ 2-year fallow period } & \multirow[b]{3}{*}{ Year } & \multicolumn{4}{|c|}{ Chemical treatment } \\
\hline & \multicolumn{2}{|c|}{ Damage of $10 \%$} & \multicolumn{2}{|l|}{ No damage } & & \multicolumn{2}{|c|}{ Damage of $25 \%$} & \multicolumn{2}{|c|}{ Damage of $30 \%$} \\
\hline & $\begin{array}{l}\text { Net benefit } \\
(€ / \text { ha) }\end{array}$ & $\begin{array}{l}\text { Density } \\
\text { (trees/ha) }\end{array}$ & $\begin{array}{l}\text { Net benefit } \\
(€ / \mathrm{ha})\end{array}$ & $\begin{array}{l}\text { Density } \\
\text { (trees/ha) }\end{array}$ & & $\begin{array}{l}\text { Net benefit } \\
(€ / \text { ha) }\end{array}$ & $\begin{array}{l}\text { Density } \\
\text { (trees/ha) }\end{array}$ & $\begin{array}{l}\text { Net benefit } \\
(€ / \text { ha) }\end{array}$ & $\begin{array}{l}\text { Density } \\
\text { (trees/ha) }\end{array}$ \\
\hline 2 & -900 & 1000 & -900 & 1000 & 0 & -930 & 1000 & -930 & 1000 \\
\hline 4 & -70 & 900 & -70 & 1000 & 2 & -70 & 750 & -70 & 700 \\
\hline 14 & 75 & 500 & 111 & 500 & 12 & 20 & 500 & 2 & 500 \\
\hline 24 & 684 & 321 & 684 & 321 & 22 & 684 & 321 & 684 & 321 \\
\hline \multirow[t]{2}{*}{37} & 7228 & 0 & 7228 & 0 & 35 & 7228 & 0 & 7228 & 0 \\
\hline & \multicolumn{2}{|c|}{$\begin{array}{l}\mathrm{NPV}_{H Y_{\text {fallow } 10}} \\
=€ 663.53 / \mathrm{ha}\end{array}$} & \multicolumn{3}{|c|}{$\begin{array}{l}\mathrm{NPV}_{H Y_{\text {fallow } 0}} \\
=€ 685.87 / \mathrm{ha}\end{array}$} & \multicolumn{2}{|c|}{$\begin{array}{l}\mathrm{NPV}_{H Y_{C T 25}} \\
=€ 727.03 / \mathrm{ha}\end{array}$} & \multicolumn{2}{|c|}{$\begin{array}{l}\mathrm{NPV}_{H Y_{C T 30}} \\
=€ 715.07 / \mathrm{ha}\end{array}$} \\
\hline
\end{tabular}

The NPV is computed taking the additional management cost of $€ 39 / \mathrm{ha} /$ year into account 
of no attack (no damage): $\operatorname{LEV}_{H Y_{\text {fallow } 10}}=€ 963.82 / \mathrm{ha}$, $\mathrm{LEV}_{H Y_{\text {fallow } 0}}=€ 979.78 / \mathrm{ha}$. The difference between these two LEVs is small $(1.5 \%)$. This is because trees damaged by the weevil are young and therefore have a low commercial value. Indeed, the net benefit of the first thinning is $€ 75 /$ ha in the case of an attack, compared to $€ 111 /$ ha in the case of no attack.

To conclude, the comparison of the LEVs of the different scenarios for Hylobius abietis: standard $\left(\mathrm{LEV}_{\mathrm{S}}\right)$, without risk handling $\left(\operatorname{LEV}_{H Y_{50}}, \operatorname{LEV}_{H Y_{65}}, \operatorname{LEV}_{H Y_{80}}\right)$, with chemical treatment $\left(\operatorname{LEV}_{H Y_{C T 25}}, \operatorname{LEV}_{H Y_{C T 30}}\right)$, with fallow $\left(\operatorname{LEV}_{H Y_{\text {fallow } 10}}, \operatorname{LEV}_{H Y_{\text {fallow } 0}}\right)$, clearly shows that the best economic option for the forest owner is to adopt the FORESTER $®$. This treatment minimizes the economic losses compared to the standard. The second best option seems to be the absence of risk handling measure when the damage is $50 \%$. In such a case, the LEV is equal to $€ 995.98 /$ ha, i.e., an economic loss of $€ 170.93 /$ ha. The third option available is fallow, with damage of 0 and $10 \%$. Finally, the worst option appeared to be the absence of risk handling measure with damage of 65 and $80 \%$. Notice that with a damage of $80 \%$, the LEV is negative and keeping the forest standing is no longer economically feasible. To conclude, the two cause-oriented measures, risk avoidance and risk prevention strategies, appear to be economically preferable to the absence of risk handling measure.

\subsection{Heterobasidion annosum}

Heterobasidion annosum is a fungus that affects coniferous trees and that is able to generate disseminated mortality in pine stands. This increase is explained by its mode of dissemination and propagation. Spores conducted by the fruiting bodies of the fungus are emitted into the air and can be carried by wind over very long distances and may infect stumps for 1 month after harvest. These spores can germinate on fresh wood, on the roots or base of the trunk, and at the level of injury or cutting lines following the harvesting of trees. The fungal strain then develops and is gradually overgrown by mycelium, and is then able to infect nearby trees, even healthy ones, by root contact, in the stand, causing mortalities. Heterobasidion annosum lacks shape retention to keep it directly in the soil of a formerly contaminated parcel, whereas it may survive in the timber if it is not completely degraded, i.e., long after the death of the tree.

We distinguish different types of cause-oriented measures for Heterobasidion annosum that are all risk prevention strategies. The first one consists of a chemical treatment on healthy plots, whose objective is to keep the probability of attack equal to zero. This treatment (Polybor ${ }^{\circledR}$ and Rotstop ${ }^{\circledR}$ ) is $100 \%$ effective (Soutrenon et al. 2000) when used before any contamination. It must be applied just after harvesting on recently harvested stumps. Another strategy is a 5 -year fallow period at the end of the rotation. Finally, other strategies such as local and total stump removal depend on the year of the contamination. Their objective is to stop or slow down dissemination. We assume that (1) contamination may occur during clearing (year 2), the first thinning (year 12) or the second thinning (year 22), (2) when contamination occurs, there are 12 contamination centers per hectare and the speed of contamination from the heart of the contamination center is equal to $0.3 \mathrm{~m} /$ year (Chantre et al. 2008).

Chemical treatment (Polybor $\AA$ and Rotstop ${ }^{\circledR}$ ) and fallow are $100 \%$ effective, so that the LEV associated with these strategies should be compared to the standard.

\subsubsection{Without risk handling measure}

For local and total stump removal, contamination may occur at year 2,12 , or 22 . Then, depending on the period of contamination, the net benefits differ from each other, as indicated in Table 4 . Note that the density remains the same

Table 4 Net benefits of a monoculture of maritime pine function of the year of contamination by Heterobasidion annosum and without risk handling measure

\begin{tabular}{|c|c|c|c|c|c|c|}
\hline \multirow[b]{2}{*}{ Year } & \multicolumn{2}{|c|}{ Contamination year 2} & \multicolumn{2}{|c|}{ Contamination year 12} & \multicolumn{2}{|c|}{ Contamination year 22} \\
\hline & $\begin{array}{l}\text { Net benefit } \\
\text { (€/ha) }\end{array}$ & $\begin{array}{l}\text { Density } \\
\text { (trees/ha) }\end{array}$ & $\begin{array}{l}\text { Net benefit } \\
(€ / \text { ha) }\end{array}$ & $\begin{array}{l}\text { Density } \\
\text { (trees/ha) }\end{array}$ & $\begin{array}{l}\text { Net benefit } \\
(€ / \text { ha) }\end{array}$ & $\begin{array}{l}\text { Density } \\
\text { (trees/ha) }\end{array}$ \\
\hline 0 & -900 & 1000 & -900 & 1000 & -900 & 1000 \\
\hline 2 & -70 & 1000 & -70 & 1000 & -70 & 1000 \\
\hline 12 & 26 & 500 & 33 & 500 & 33 & 500 \\
\hline 22 & 503 & 321 & 580 & 321 & 606 & 321 \\
\hline \multirow[t]{2}{*}{35} & 4453 & 0 & 5840 & 0 & 6731 & 0 \\
\hline & \multicolumn{2}{|c|}{$\mathrm{NPV}_{H E_{2}}=€-44.07 / \mathrm{ha}$} & \multicolumn{2}{|c|}{$\mathrm{NPV}_{H E_{12}}=€ 411.94 / \mathrm{ha}$} & \multicolumn{2}{|c|}{$\mathrm{NPV}_{H E_{22}}=€ 691.33 / \mathrm{ha}$} \\
\hline
\end{tabular}

The NPV is computed taking the additional management cost of $€ 39 / \mathrm{ha} /$ year into account 
regardless of the scenario. However, the commercial value of contaminated trees is 0 .

Using Eq. 3, we compute the LEV function of the period of contamination, year 2,12 , or 22 , as follows: $\mathrm{LEV}_{H E_{2}}=€-62.95 / \mathrm{ha}, \mathrm{LEV}_{H E_{12}}=€ 588.46 / \mathrm{ha}$, $\mathrm{LEV}_{H E_{22}}=€ 987.58 / \mathrm{ha}$. As expected, the earlier the contamination is, the lower the LEV will be since more trees are contaminated as the fungus spreads over time at a speed of $0.3 \mathrm{~m} /$ year. The LEV may even be negative if contamination occurs at the very beginning of the rotation, making the conservation of the stand economically irrelevant.

\subsubsection{Chemical treatment: Polybor ${ }^{\circledR}$ and Rotstop ${ }^{\circledR}$}

We assume that chemical treatment on healthy plots costs $€ 1 / \mathrm{m}^{3}$ of wood removed from the forest. With this treatment, the probability of attack is zero and so is the damage. The values in Table 1 are modified to include the cost of the treatment, and the associated NPV is $\mathrm{NPV}_{H E_{C T}}=$ $€ 594.14 /$ ha.

We compute the LEV associated with this treatment following Eq. 3: $\mathrm{LEV}_{H E_{C T}}=€ 848.74 /$ ha. The treatment reduces the LEV by $27 \%$ compared to the standard but guarantees the absence of contamination. Compared to previous LEVs without risk handling measure, it appears that chemical treatment is always economically relevant except when contamination occurs late in the stand (during the last thinning).

\subsubsection{Fallow strategy}

Heterobasidion annosum is unable to remain in the soil in the absence of wood, and the root system of the maritime pine rapidly degrades. After a clear-cutting of the stand affected by Heterobasidion annosum, the forest owner just has to wait for a sufficient degradation of the stumps to block contamination of the next stand. The degradation speed depends on the climate conditions and the $\mathrm{pH}$ of the soil and ranges from a few years to a decade. Consistent with Greig (1984), we assume that a 5-year fallow period prevents the development of the fungus. We assume here that, previous to the new rotation, the stand was contaminated. Consequently, the rotation goes from year 5 to 40 (compared to year 0 to 35 in the standard). The values in Table 1 are modified to include the higher rotation length, and the corresponding NPV is NPV E $_{\text {fallow }}=€ 687.77 / \mathrm{ha}$. The LEV for the fallow strategy is then computed using Eq. 3 and is equal to $\operatorname{LEV}_{H E_{\text {fallow }}}=€ 987.58 / \mathrm{ha}$. First, the comparison between the fallow and the standard shows that a fallow period leads to an economic loss of $€ 179.33 / \mathrm{ha}$, i.e., the difference between the two LEVs, $€ 1166.91 /$ ha and $€ 987.58 / \mathrm{ha}$. Second, we can observe that a fallow period is always preferable to chemical treatment with Polybor ${ }^{\circledR}$ and Rotstop®.

\subsubsection{Local and total stump removal}

Total stump removal makes it possible to clean the plot by removing the roots where the fungus can remain and eventually contaminate the stand of the next generation if the old and new root stand are in contact. Heterobasidion annosum spreads in the stand via the roots and creates stains around the contamination points. Therefore, local stump removal on an area of at least each fungus propagation stain may also isolate the problem. We assume that the total stump removal costs €690/ha. In the case where stumps are locally removed, only stumps in the contaminated area are removed. The contaminated area depends on the age of contamination: the earlier the contamination occurs, the bigger the contamination area will be. Tables 5 and 6 present the NPV for these strategies according to the date of contamination.

Table 5 Net benefits of a monoculture of maritime pine function of the year of contamination by Heterobasidion annosum under local stump removal

\begin{tabular}{|c|c|c|c|c|c|c|}
\hline \multirow[b]{2}{*}{ Year } & \multicolumn{2}{|c|}{ Contamination year 2} & \multicolumn{2}{|c|}{ Contamination year 12} & \multicolumn{2}{|c|}{ Contamination year 22} \\
\hline & $\begin{array}{l}\text { Net benefit } \\
(€ / \text { ha) }\end{array}$ & $\begin{array}{l}\text { Density } \\
\text { (trees/ha) }\end{array}$ & $\begin{array}{l}\text { Net benefit } \\
(€ / \text { ha) }\end{array}$ & $\begin{array}{l}\text { Density } \\
\text { (trees/ha) }\end{array}$ & $\begin{array}{l}\text { Net benefit } \\
(€ / \text { ha) }\end{array}$ & $\begin{array}{l}\text { Density } \\
\text { (trees/ha) }\end{array}$ \\
\hline 0 & -900 & 1000 & -900 & 1000 & -900 & 1000 \\
\hline 2 & -70 & 750 & -70 & 700 & -70 & 700 \\
\hline 12 & 75 & 500 & 111 & 500 & 111 & 500 \\
\hline 22 & 653 & 321 & 624 & 321 & 684 & 321 \\
\hline \multirow[t]{2}{*}{35} & 6928 & 0 & 6928 & 0 & 6697 & 0 \\
\hline & \multicolumn{2}{|c|}{$\mathrm{NPV}_{H E_{L S R 2}}=€ 688.81 / \mathrm{ha}$} & \multicolumn{2}{|c|}{$\mathrm{NPV}_{H E_{L S R 12}}=€ 699.18 / \mathrm{ha}$} & \multicolumn{2}{|c|}{$\mathrm{NPV}_{H E_{L S R 22}}=€ 657.51 / \mathrm{ha}$} \\
\hline
\end{tabular}

The NPV is computed taking the additional management cost of $€ 39 / \mathrm{ha} /$ year into account 
Table 6 Net benefits of a monoculture of maritime pine function of the year of contamination by Heterobasidion annosum under total stump removal

\begin{tabular}{|c|c|c|c|c|c|c|}
\hline \multirow[b]{2}{*}{ Year } & \multicolumn{2}{|c|}{ Contamination year 2} & \multicolumn{2}{|c|}{ Contamination year 12} & \multicolumn{2}{|c|}{ Contamination year 22} \\
\hline & $\begin{array}{l}\text { Net benefit } \\
\text { (€/ha) }\end{array}$ & $\begin{array}{l}\text { Density } \\
\text { (trees/ha) }\end{array}$ & $\begin{array}{l}\text { Net benefit } \\
(€ / \text { ha) }\end{array}$ & $\begin{array}{l}\text { Density } \\
\text { (trees/ha) }\end{array}$ & $\begin{array}{l}\text { Net benefit } \\
\text { (€/ha) }\end{array}$ & $\begin{array}{l}\text { Density } \\
\text { (trees/ha) }\end{array}$ \\
\hline 0 & -900 & 1000 & -900 & 1000 & -900 & 1000 \\
\hline 2 & -70 & 750 & -70 & 700 & -70 & 700 \\
\hline 12 & 105 & 500 & 108 & 500 & 111 & 500 \\
\hline 22 & 581 & 321 & 658 & 321 & 684 & 321 \\
\hline \multirow[t]{2}{*}{35} & 3841 & 0 & 5228 & 0 & 6119 & 0 \\
\hline & \multicolumn{2}{|c|}{$\mathrm{NPV}_{H E_{T S R 2}}=€-251.05 / \mathrm{ha}$} & \multicolumn{2}{|c|}{$\mathrm{NPV}_{H E_{T S R 12}}=€ 204.95 / \mathrm{ha}$} & \multicolumn{2}{|c|}{$\mathrm{NPV}_{H E_{T S R 22}}=€ 484.35 / \mathrm{ha}$} \\
\hline
\end{tabular}

The NPV is computed taking the additional management cost of $€ 39 / \mathrm{ha} /$ year into account

On the basis of these NPVs, we compute the LEVs for each strategy function of the year of contamination, using Eq. 3. For local stump removal, the LEVs are $\mathrm{LEV}_{H E_{L S R 2}}=€ 983.98 / \mathrm{ha}, \mathrm{LEV}_{H E_{L S R 12}}=€ 998.80 / \mathrm{ha}$, $\mathrm{LEV}_{H E_{L S R 22}}=€ 939.27 / \mathrm{ha}$. For total stump removal, the LEVs are $\mathrm{LEV}_{H E_{T S R 2}}=€-358.63 / \mathrm{ha}, \mathrm{LEV}_{H E_{T S R 12}}=$ $€ 292.78 / \mathrm{ha}, \mathrm{LEV}_{H E_{T S R 22}}=€ 691.90 / \mathrm{ha}$.

To conclude, the comparison of the LEV of the different scenarios for Heterobasidion annosum: standard $\left(\mathrm{LEV}_{\mathrm{S}}\right)$, without risk handling $\left(\mathrm{LEV}_{H E_{2}}, \mathrm{LEV}_{H E_{12}}\right.$, $\left.\mathrm{LEV}_{H E_{22}}\right)$, with chemical treatment $\left(\operatorname{LEV}_{H E_{C T}}\right)$, with a fallow $\left(\mathrm{LEV}_{H E_{\text {fallow }}}\right)$, with local stump removal ( $\mathrm{LEV}_{H E_{L S R 2} \text {, }}$, $\mathrm{LEV}_{H E_{L S R 12}}$, $\mathrm{LEV}_{H E_{L S R 22}}$ ), and total stump removal $\left(\mathrm{LEV}_{H E_{T S R 2}}, \mathrm{LEV}_{H E_{T S R 12}}, \mathrm{LEV}_{H E_{T S R 22}}\right)$ leads to several comments. First, regardless of the date of contamination, comparing chemical treatment with Polybor ${ }^{\circledR}$ and Rotstop ${ }^{\circledR}$ to stump removal leads to the following conclusion: local stump removal is always preferable to chemical treatment, whereas chemical treatment is always preferable to total stump removal. Second, we can observe that, regardless of the date of contamination, fallow is always preferable to total stump removal, whereas local stump removal is preferable to fallow for a contamination at year 12. In addition, our results suggest that when contamination occurs at year 22, the absence of risk handling measure may be preferable both to local and total stump removal. Finally, comparing these two stump removal strategies together reveals that local stump removal seems to be more effective than total stump removal.

\section{Discussion}

We first discuss limitations and future extensions of our approach, and then, we relate our results to adaptation to climate change and multi-hazards perspective.

\subsection{Limitations and extensions}

First, we assume in Section 3.2 that trees contaminated with Heterobasidion annosum do not have any commercial value. However, as Heterobasidion annosum starts from the stump, there might be uninfected parts in the upper half of the stem. These uninfected parts may have a commercial value and may be used, for example, as fuelwood. A way to consider these uninfected parts of the tree would be to include their commercial value in the model. In this view, we tested a scenario in which commercial value of contaminated tree is valued at half of the healthy tree value. Using Eq. 3, we calculated the LEV of this scenario without risk handling measure and function of the year of contamination: $\mathrm{LEV}_{H E_{\text {fuel } 2}}=€ 551.97 / \mathrm{ha}, \mathrm{LEV}_{H E_{\text {fuel } 12}}=€ 877.7 / \mathrm{ha}$, $\mathrm{LEV}_{H E_{\text {fuel } 22}}=€ 1077.24 / \mathrm{ha}$. In this case, the absence of risk handling measure may be preferable to any solution if contamination occurs at year 22. If contamination occurs at year 12 , only fallow and local stump removal better perform, while only total stump removal is less preferable if contamination occurs at year 2 . These results call for further analysis which would explicitly take the final uses of wood in process industries into account in order to compute a range of benefits depending on the quality of wood products.

Second, we consider in our model that the landowner's objective is to maximize the Land Expectation Value. By doing that, the owner behaves as a risk neutral profitmaximizer. However, the literature shows that risk aversion may play a significant role in the forest owner's management decision (Yousefpour et al. 2012; Brunette et al. 2014). For example, Alavrez and Koskela (2006) show that risk aversion decreases the optimal harvesting age, and Uusivuori (2002) predicts that if the owner's risk aversion decreases as wealth increases, then the standing timber stock will increase in the future, and the intensity of timber harvests will decline. Consequently, a promising 
way of extension of our model may be to consider a risk averse forest owner. For that purpose, several approaches are proposed in the literature, among them expected-utility framework, option pricing models, and robust optimization (see Hildebrandt and Knoke 2011 for a more detailed presentation).

Third, forest ecosystem services such as carbon sequestration or its role as a biodiversity sanctuary are also impacted by phytosanitary problems. This should be considered in a comprehensive analysis of the economic impacts of phytosanitary risks over forest stands.

\subsection{Adaptation to climate change}

In plantation forests, several adaptation strategies exist. They generally involve the change of species and/or clones more adapted to new conditions, the preference for mixedspecies stands, additional management operations (such as fallow or stump removal), or conventional chemical treatments. Compared to other strategies, these conventional treatments appear to be rather conservative since they do not imply any changes in forest management choices. Two of the cause-oriented risk handling measures considered in our paper belong to this category: the FORESTER ${ }^{\circledR}$ for Hylobius abietis and Polybor ${ }^{\circledR}$ and Rotstop ${ }^{\circledR}$ for Heterobasidion annosum. Although cypermethrin solution performs better than other strategies to handle the risk of Hylobius abietis, one may question the long-term implications of this strategy in a context of climate change. In fact, this option makes it possible to conserve production activity on the short-term while maintaining (or even increasing) exposure and vulnerability of maritime pine monoculture on the long-term. In line with Noble et al. (2014), this strategy can therefore be considered as a maladaptation since it results in shortterm economic gains but leads to greater vulnerability on the medium- to long-term.

Conversely, it has been shown that spreading risk by promoting mixed-species stands whose resilience to forest phytosanitary issues is greater than monocultures, combined with natural regeneration (Kramer et al. 2010), is a relevant adaptation strategy for temperate forests (Hemery 2008; Bolte et al. 2010). Species and origins must be chosen function of future potential climatic conditions, which are likely to shift from several $\mathrm{km}$ to several tens of $\mathrm{km}$ per decade, probably faster than natural migration.

Other strategies studied in our paper (stump removal and fallow) remain in-between, allowing for more flexibility in management practices but nevertheless maintaining the monospecies type of management.

In conclusion, we strongly believe that there is an increasing need for more resilience-based adaptation strategies within plantation forests. The impacts of the introduction of mixed-species stands or genetically-selected clones could be questionned, and it would be necessary to take the modification of harvest methods, machines, and processes into account, as well as the potential requirements in research and development.

\subsection{Multi-hazards perspective}

In this paper, we focus on Hylobius abietis and Heterobasidion annosum separately, without considering potential dependence between them or with other natural events. However, in practice, several risks may be dependent or the occurrence of a phytosanitary problem may be the consequence of the occurrence of another natural event.

In the literature, some papers deal with the interactions between several risks. For example, Parker et al. (2006) analyze the interactions among fire, insects, and pathogens in coniferous forests in the USA and Canada. Focusing on the forest insurance against natural events, Brunette et al. (2015) deepen the analysis of the link between several randomly occurring natural hazards (storm, insects, and fire). They consider that the natural hazards are either mutually dependent or mutually independent. They conclude that the results change with the considered assumption.

In France, Desprez-Loustau et al. (2006) focus on the link between drought risk and pathogen invasion. In addition, Lung-Escarmant and Maugard (2004) found that Heterobasidion annosum was detected mainly on wind-fallen stumps in more than $95 \%$ of the analyzed stands and concluded that Heterobasidion annosum is truly a risk that must be taken into account for the management and the restoration of wind-damaged stands in the Landes de Gascogne Forest.

Such an interaction between Heterobasidion annosum and storms would benefit from considering other risk handling strategies. In this paper, we focus on strategies that directly and exclusively affect the risks that we focus on, Heterobasidion annosum and Hylobius abietis. In the case of the Landes de Gascogne Forest, recommendations concerning phytosanitary problems are numerous and we analyze only some of them: fallow, species diversification, reduction of rotation length (Piou and Jactel 2010; Vert et al. 2013). These strategies of diversification and reduction of rotation length act not only on the risks analyzed in this paper but also on other risks such as storm, for example, so that the associated costs and benefits of these strategies are more difficult to isolate. A multi-hazards perspective would make it possible to consider these relevant strategies.

\section{Conclusion}

This paper aims to compare different cause-oriented handling measures for Hylobius abietis and Heterobasidion annosum through standard forest economics methodology, 
i.e., a comparison of the LEV of each strategy. This approach makes it possible to display the most costly scenario without risk, with risk and without risk handling measure, and with risk and with risk handling measure (risk prevention and risk avoidance). Our results indicate that for Hylobius abietis, the measures analyzed, a fallow strategy and a chemical treatment, are always preferable to the scenario without risk handling. In this case, risk handling measures appear to be economically relevant. More precisely, the loss is the lowest (compared to the standard without risk) with the FORESTER $®$ and a mortality rate of $25 \%$ (loss $=€ 128.32 / \mathrm{ha}$ ), and the highest without risk handling and a mortality rate of $80 \%$ (loss $=€ 1854.8 / \mathrm{ha}$ ). In addition, we showed that one important driver of economic loss is the impact of the phytosanitary risk on the final stand density. Indeed, we showed that Hylobius abietis does not only decrease economic gains by reducing the economic value of contaminated trees but also by reducing the overall density, which results in a non-proportional LEV decrease over time.

For Heterobasidion annosum, the results depend on the year of contamination. If the contamination occurs at year 2 , then the best option seems to be the fallow compared to the standard without risk (loss $=€ 179.33 / \mathrm{ha}$ ). The following more effective options are local stump removal, Polybor ${ }^{\circledR}$ and Rotstop ${ }^{\circledR}$, no risk handling and total stump removal, respectively, with the last two associated with negative LEVs. If the contamination occurs at year 12, then the most economically relevant scenario is the one with a local stump removal (loss $=€ 168.11 / \mathrm{ha}$ ). The following preferable options are, respectively, fallow, Polybor ${ }^{\circledR}$ and Rotstop ${ }^{\circledR}$, no risk handling, and total stump removal. Finally, if the year of contamination is 22 , then the absence of risk handling measure is preferable from an economic point of view (loss $=€ 179.33 / \mathrm{ha}$ ). The following more effective options are, respectively, fallow, local stump removal, Polybor ${ }^{\circledR}$ and Rotstop®, and total stump removal.

Nevertheless, our paper shows that the absence of risk handling measure may sometimes be the best option in economic terms. More broadly, it should be noted that we proposed here a generic method that could be improved taking into account potential long-term impacts of risk handling measures. In particular one may assume that options increasing the resilience of the forest system and decreasing its vulnerability over the long term should be preferred. To test this assumption, one solution would be to couple our cost-benefit approach with a multi-impact Modelling framework describing the forest system on the long term and its environmental and economic relationships with other sectors.

Acknowledgments We acknowledge Alcina and, in particular, Sébastien Diette for the funding of this research project. We also thank
Alexandre Gourdy for the work realized during his trainee position at the Laboratory of Forest Economics. The UMR Economie Forestière is supported by a grant overseen by the French National Research Agency (ANR) as part of the "Investissements d'Avenir" program (ANR-11-LABX-0002-01, Lab of Excellence ARBRE).

\section{References}

Alavrez LHR, Koskela E (2006) Does risk aversion accelerate optimal forest rotation under uncertainty? J For Econ 12:171-184

Amacher GS, Malik AS, Haight RG (2005) Not getting burner: the importance of fire prevention in forest management. Land Econ 81:284-302

Bentz BJ, Régnière J, Fettig CJ, Hansen EM, Hayes JL, Hicke JA, Kelsey RG, Negron JF, Seybold SJ (2010) Climate change and bark beetles of the Western United States and Canada: direct and indirect effects. Bioscience 60:602-613

Berggren A, Björkman C, Bylund H, Ayres M (2009) The distribution and abundance of animal populations in a climate of uncertainty. Oikos 118:1121-1126

Bolte A, Hilbrig L, Grundmann B, Kampf F, Brunet J, Roloff A (2010) Climate change impacts on stand structure and competitive interactions in a southern Swedish spruce-beech forest. Eur J For Res 129(3):261-276

Brunette M, Costa S, Lecocq F (2014) Economics of species change subject to risk of climate change and increasing information: a (quasi-)option value analysis. Ann For Sci 71(2):279_ 290

Brunette M, Holecy J, Sedliak M, Tucek J, Hanewinkel M (2015) An actuarial model of forest insurance against multiple natural hazards in fir (Abies Alba Mill.) stands in Slovakia. For Policy Econ 55:46-57

Canteloup D, Castro A (2012) Situation sanitaire et diversification. Les Cahiers de la Reconstitution 2:1-12

Chantre et al. (2008) Rapport final du projet "Sylvogène" du Pôle de compétitivité XYLOFUTUR, 235p

Desprez-Loustau ML, Marçais B, Nageleisen LM, Piou D, Vannini A (2006) Interactive effects of drought and pathogens in forest trees. Ann For Sci 63:597-612

Desprez-Loustau ML, Robin C, Reynaud G, Déqué M, Badeau V, Piou D, Husson C, Marçais B (2007) Simulating the effects of a climate change scenario on geographical range and activity of forest pathogenic fungi. Can J Plant Pathol 29:101-120

Desprez-Loustau ML, Courtecuisse R, Robin C, Husson C, Moreau PA, Blancard D, Selosse MA, Lung-Escarmant B, Piou D, Sache I (2010) Species diversity and drivers of spread of alien fungi (sensu lato) in Europe with a particular focus on France. Biol Invasions 12:157-172

FAO (2008) Climate change impacts on forest health. Food and Agriculture Organization, Rome

Faustmann M (1849) Berechnung des werthes, welchen waldboden, sowie noch nicht haubare holzbestände für die waldwirtschaft besitzen Allgemeine forst- und jagdzeitung, vol 15(12), pp S. 441-455

Gonthier P, Brun F, Lione G, Nicolotti G (2012) Modelling the incidence of Heterobasidion annosum butt rots and related economic losses in alpine mixed naturally regenerated forests of Northern Italy. For Pathol 42(1):57-68

Goodnow R, Sullivan J, Amacher GS (2008) Ice damage and forest stand management. J For Econ 14:268-288

Greig BJW (1984) Management of East England pine plantations affected by Heterobasidion annosum root rot. Eur J For Pathol 14(7):392-397 
Hahn A, Knoke T (2010) Sustainable development and sustainable forestry: analogies, differences, and the role of flexibility. Eur $\mathrm{J}$ For Res 129:787-801

Hanewinkel M, Hummel S, Cullmann A (2010) Modelling and economic evaluation of forest biome shifts under climate change in Southwest Germany. For Ecol Manage 259:710-719

Hanewinkel M, Hummel S, Albrecht A (2011) Assessing natural hazards in forestry for risk management: a review. Eur J For Res 130:329-351

Hemery GE (2008) Forest management and silvicultural responses to projected climate change impacts on European broadleaved trees and forests. Int For Rev 10(4):591-607

Heritage S, Moore R (2000) The assessment of site characteristics as part of a management strategy to reduce damage by Hylobius. Forestry Commission Information Note 38

Hildebrandt $P$, Knoke T (2011) Investment decisions under uncertainty - a methodological review on forest science studies. For Policy Econ 13:1-15

Hogg EH, Brandt JP, Michaelian M (2008) Impact of a regional drought on the productivity, dieback and biomass of western Canadian aspen forests. Can J For Res 38:1373-1384

Jactel H, Brockerhoff EG (2007) Tree diversity reduces herbivory by forest insects. Ecol Lett 10(9):835-848

Jactel H, Brockerhoff E, Piou D (2008) Disease risk in mixed forests. Rev For Fr 60(2):168-180

Jactel H, Nicoll BC, Branco M, Gonzalez-Olabarria J, Grodzki W, Längström B, Moreira F, Netherer S, Orazio C, Piou D, Santos H, Schelhaas MJ, Tojic K, Vodde F (2009) The influences of forest stand management on biotic and abiotic risks of damage. Ann For Sci 66(7):1-18

Jactel H, Desprez-Loustau ML, Marçais B, Piou D, Robinet C, Roques A (2012) Évolution des risques biotiques en forêt. Innov Agron 18:87-94

Klemperer WD (1996) Forest resource economics and finance. McGraw-Hill, New-York

Knight F (1921) Risk, uncertainty and profit. Houghton Mifflin, Boston

Knoke T, Ammer C, Stimm B, Mosandl R (2008) Admixing broadleaved to coniferous tree species: a review on yield, ecological stability and economics. Eur J For Res 127(2):89-101

Kovats S, Valentini R, Bouwer LM, Georgopoulou E, Jacob D, Martin E, Rounsevell M, Soussana JF (2014) Terrestrial and inland water systems. In: Climate change 2014: impacts, adaptation and vulnerability. Contribution of working group II to the fifth assessment report of the IPCC. Cambridge University Press, Cambridge

Kramer K, Degen B, Buschbom J, Hickler T, Thuiller W, Sykes MT, de Winter W (2010) Modelling exploration of the future of European beech (Fagus sylvatica L.) under climate changerange, abundance, genetic diversity and adaptive response. For Ecol Manage 259(11):2213-2222

Lung-Escarmant B, Maugard F (2004) Conséquences phytosanitaires de la tempête du 27 décembre 1999: évaluation du risque fomes (Heterobasidion annosum) dans le massif landais. Les cahiers du DSF (La Santé des forêts [France]) 1:78-81

Michaelian M, Hogg EH, Hall RJ, Arsenault E (2011) Massive mortality of aspen following severe drought along the southern edge of the Canadian boreal forest. Glob Chang Biol 17(6):20842094
Mora O, Banos V, Regolini M, Carnus JM (2014) Using scenarios for forest adaptation to climate change: a foresight study of the Landes de Gascogne Forest 2050. Ann For Sci 71(3):313-324

Neuner S, Beinhofer B, Knoke T (2013) The optimal tree species composition for a private forest enterprise - Applying the theory of portfolio selection. Scand J For Res 28(1):38-48

Noble I, Huq S, Anokhin Y, Carmin J, Goudou D, Lansigan F, OsmanElasha B, Villamizar A (2014) Adaptation needs and options. In: Climate change 2014: impacts, adaptation and vulnerability. Contribution of working group II to the fifth assessment report of the IPCC. Cambridge University Press, Cambridge

Parker IM, Gilbert GS (2004) The evolutionary ecology of novel plantpathogen interactions. Annu Rev Ecol Evol Syst 35:675-700

Parker TJ, Clancy KM, Mathiasen RL (2006) Interactions among fire, insects and pathogens in coniferous forests of the interior western United States and Canada. Agric For Entomol 8:167-189

Piou D, Jactel H (2010) L'avenir du massif forestier des Landes de Gascogne. Rapport d'expertise sur l'évaluation des risques biotiques. http://landes.gip-ecofor.org/data/RFC40310.pdf. Accessed July 2015

Reed WJ (1987) Protecting a forest against fire: optimal protection patterns and harvest policies. Nat Resour Model 2:23-53

Roessiger J, Griess VC, Knoke T (2011) May risk aversion lead to near-natural forestry? A simulation study. Forestry 84(5):527-537

Roques A, Rabitsch W, Rasplus JY, Lopez-Vamonde C, Nentwig W, Kenis M (2009) Alien terrestrial invertebrates of Europe. In: Daisie (ed) Handbook of alien species in Europe. Springer, Berlin

Rouault G, Candau JN, Lieutier F, Nageleisen LM, Martin JC, Warzee $\mathrm{N}$ (2006) Effects of drought and heat on forest insect populations in relation to the 2003 drought in Western Europe. Ann For Sci 63:613-624

Scholes R, Settele J, Betts R, Bunn S, Leadley P, Nepstad D, Overpeck J, Angel Taboada M (2014) Terrestrial and inland water systems. In: Climate change 2014: impacts, adaptation and vulnerability. Contribution of working group II to the fifth assessment report of the IPCC. Cambridge University Press, Cambridge

Soutrenon A, Lévy A, Legrand P, Lung-Escarmant B, SylvestreGuinot G (2000) Efficacité de trois traitements de souches contre le fomès (Heterobasidion annosum) sur pin maritime. Rev For Fr $1: 39-48$

Thorsen BJ, Helles F (1998) Optimal stand management with endogenous risk of sudden destruction. For Ecol Manage 108:287-299

Uusivuori J (2002) Non-constant risk attitudes and timber harvesting. For Sci 48:459-470

Vert J, Schaller N, Villien C (2013) Agriculture Forêt Climat: vers des stratégies d'adaptation. Centre d'études et de prospective, Ministère de l'Agriculture, de l'Agroalimentaire et de la Forêt. http://agriculture.gouv. fr/agriculture-foret-climat-vers-des-strategies-dadaptation. Accessed July 2015

Woodward S, Stenlid J, Karjalainen R, Hüttermann A (1998) Heterobasidion annosum: biology, ecology impact and control. Wallingford, UK

Yoder J (2004) Playing with fire: endogenous risk in resource management. Am J Agric Econ 86:933-948

Yousefpour R, Jacobsen JB, Thorsen BJ, Meilby H, Hanewinkel M, Oehler K (2012) A review of decision-making approaches to handle uncertainty and risk in adaptive forest management under climate change. Ann For Sci 69:1-15 